\title{
Nephroprotective activity of the enriched polyphenol extract of Euterpe edulis Martius
}

\author{
Priscylla Maria Martins Cardosoํ, Renata Alves Mazuco', Lucas Soares Dazzi Macedo1, \\ Ariele Abreu Venturini Polese ${ }^{1}$, Maria Eduarda de Souza Barroso', Waléria Gramilich Baratella ${ }^{1}$, \\ Tadeu Uggere de Andrade ${ }^{1}$, Dominik Lenz ${ }^{1}$, Thiago de Melo Costa Pereira ${ }^{1,2 \#,}$ \\ Denise Coutinho Endringer ${ }^{\circledR 1,2 \# *}$
}

\begin{abstract}
${ }^{1}$ Pharmaceutical Sciences Program, Universidade Vila Velha, Vila Velha, ES, ${ }^{2}$ Federal Institute of Education, Science and Technology of Espírito Santo, Vila Velha, ES, Brazil
\end{abstract}

\begin{abstract}
Contrast-induced nephropathy (NIC) is directly related to increased morbidity and mortality, and its treatment and prevention might be achieved by the administration of antioxidant products. The juçara palmetto (Euterpe edulis Martius) has fruits rich in phenolic compounds, which are known for their antioxidant activity. This work aimed to evaluate the nephroprotective activity of E. edulis pulp in the NIC animal model. The collected fruits were pulped, their contents of polyphenols and anthocyanins were quantified, and their antioxidant activity were evaluated. The nephroprotective effects were determined based on iodine contrast induction and evaluated by biochemical and histological analyses. The results showed that $E$. edulis pulp was rich in polyphenols $(811 \pm 16.7 \mathrm{mg}$ EAG/g) and anthocyanins $(181.25 \mathrm{mg} / 100 \mathrm{~g})$ and had very strong antioxidant activity, as demonstrated by the DPPH (2,2-diphenyl-1picryl-hydrazyl) method, which revealed an antioxidant activity index (AAI) of 3.4, and the 2,29-azinobis (3-ethylbenzothiazoline-6-sulfonic acid) (ABTS) method, which revealed an $\mathrm{IC}_{50}$ of $0.59 \pm 0.03 \mathrm{mg} / \mathrm{mL}$. In the in vivo experiments, E. edulis pulp tended to provide renal protection and reduce renal dysfunction and tubular morphological lesions in mice after the induction of NIC, and these effects were obtained through the antioxidant activities of the polyphenols in the pulp.
\end{abstract}

Keywords: Nephroprotection. Euterpe edulis Martius. Polyphenols. Anthocyanins. Antioxidant activity.

\section{INTRODUCTION}

Acute renal injury, which is also known as contrast nephropathy (NIC), is an iatrogenic condition caused by procedures involving the administration of iodinated contrast agents, which are often used in imaging diagnostics. Moreover, as the third leading cause of renal insufficiency acquired in a hospital environment, NIC is also associated with increased morbidity and mortality (Santos et al., 2011). The use of iodinated contrast media during some procedures, including coronary angiography and percutaneous coronary intervention, might cause acute renal injury, the most common cause of which is acute renal failure (Kaye et al., 2014). Impaired renal function is often noted due to changes in routine

\footnotetext{
*Correspondence: D. C. Endringer. Programa de Pós-graduação em Ciências Farmacêuticas, Universidade Vila Velha. Av. Comissário José Dantas de Melo, 21, CEP: 29102-920, Vila Velha, ES, Brazil. Phone: +55-2734212191. E-mail: denise.endringer@uvv.br, \# Equivalent contributions
}

laboratory tests, such as urea and particularly creatinine (Magro, Vattimo, 2007).

The exact pathogenesis of NIC is currently under debate, but it has been confirmed that NIC is caused by a combination of factors (Osthoff, Trendelenburg, 2013; Andreucci et al., 2014), such as renal and vascular tubular injury accompanied by direct and indirect influences of reactive oxygen species (EROs) (Heyman et al., 2010). Sufficient histological changes, particularly at proximal tubular lesions, are observed in NIC, and these result in a reduction of the glomerular filtration rate due to the iodinated contrast agent (Billings et al., 2008; Andreucci et al., 2014; Diogo, Bahlis, Carvalhal, 2014). A factor that has been adopted in the selection of products that can prevent NIC is antioxidant activity (Andreucci et al., 2014). As a result, N-acetylcysteine (NAC), ascorbic acid (vitamin $\mathrm{C}$ ) and $\alpha$-tocopherol (vitamin $\mathrm{E}$ ) have been tested as agents for the prevention of NIC (Pattharanitima, Tasanarong, 2014; McCullough, Akrawinthawong, 2013), 
and $\mathrm{N}$-acetylcysteine is the only agent that forms part of the currently used prophylactic regimen.

The fruits of the juçara palmetto (Euterpe edulis Martius), which belongs to the Arecaceae family, contain phenolic compounds with antioxidant activity, including anthocyanins (Paredes-López et al., 2010; Borges et al., 2011a; Inácio et al., 2013; Bicudo, Ribani, Beta, 2014). The anthocyanins have been identified in E. edulis fruits are cyanidin 3-O-glycoside, which is the major anthocyanin in the fruits, and cyanidin 3-O-rutinoside, cyanidin-3,5-diglycoside, pelargonidin 3-O-rutinoside, peonidin-3-O-glycoside, peonidin 3-O-rutinoside, cyanidin 3-sambubioside and cyanidin 3-ramnoside, which are found in lower quantities (Bicudo, Ribani, Beta, 2014; Ribeiro et al., 2011; Brito et al., 2007).

As part of the search for new alternative products for the prevention of NIC that could be used as a functional food, this study aimed to evaluate whether E. edulis pulp can be used for the prevention of NIC in an experimental model.

\section{MATERIAL AND METHODS}

\section{Plant material}

Fruits of E. edulis were supplied by Incaper and collected in the region of Rio Novo do Sul-ES in August 2013. A voucher specimen was prepared and identified by Prof. M.Sc. Solange Z. Schneider, a botanist at the herbarium at University Vila Velha (UVV), and deposited at this herbarium under the number UVVES2396.

Approximately $1 \mathrm{~kg}$ of fruits was pulped according to the pulping technique used by the local population and immersed in water at $40^{\circ} \mathrm{C}$ for 60 minutes to release the pulp and seeds. Soon after, the seeds and pulp were separated by sieving. The material was lyophilized (Labconco Freezone ${ }^{\circledR}$ lyophilizer, model 7752020, USA) at a rate of approximately $10 \mathrm{~mL} /$ day until the liquid was completely evaporated and a purple powder was obtained. This powder was then stored in a refrigerator at $-20^{\circ} \mathrm{C}$ until use in the experiments.

\section{Evaluation of DPPH antioxidant capacity}

The antioxidant activity of E. edulis pulp was determined using the 2,2-diphenyl-1-picryl-hydrazyl (DPPH) free radical method (Scherer, Godoy, 2009). The minimum inhibitory concentration required to inhibit $50 \%$ of the initial free radical concentration $\left(\mathrm{CI}_{50}\right)$ was calculated using the equation of the straight line obtained from the calibration curve relating the concentration to the potential DPPH radical inhibition. The antioxidant action of the pulp was expressed using the Antioxidant Activity Index (IAA), which is the ratio of the concentration of DPPH $(\mu \mathrm{g} / \mathrm{mL})$ to the $\mathrm{CI}_{50}(\mu \mathrm{g} / \mathrm{mL})$, and classified according to the IAA value obtained (weak if IAA $<0,5$, moderate if the $0.5<\mathrm{AAI}<1$, strong if $1<\mathrm{AAI}<2$, and very strong if AAI $>2)$. Ferulic acid ( 0.89 to $4.7 \mu \mathrm{g} / \mathrm{mL}$ and $\mathrm{R}_{2}$ 0.99 ) was employed as a positive control in the antioxidant activity determination.

\section{Evaluation of ABTS antioxidant capacity}

The 2,2'-azino-bis-(3-ethylbenzothiazoline-6sulfonic acid) (ABTS) radical assay was performed according to the methodology described by Re et al. (1999) with some modifications. Specifically, the experiment was performed in 96-well plates, absolute ethanol was used as the blank, and $250 \mu \mathrm{L}$ of the ABTS radical solution $+20 \mu \mathrm{L}$ of ethanol was used as the control. The samples consisted of $250 \mu \mathrm{L}$ of the ABTS radical solution and $20 \mu \mathrm{L}$ of the E. edulis pulp solutions (1.0 to $0.15 \mathrm{mg} / \mathrm{mL}$ ). The same experiment was performed using BHT antioxidant standards ( 0.62 to $0.08 \mathrm{mg} / \mathrm{mL})$, TBHQ $(0.56$ to $0.07 \mathrm{mg} / \mathrm{mL})$ and quercetin $(0.3$ to $0.006 \mathrm{mg} / \mathrm{mL})$. The percentage of inhibition read at the wavelength of $734 \mathrm{~nm}$ was related to the concentration of the pulp or standards, and the $\mathrm{CI}_{50}$ was calculated from the equation of the line obtained for each solution. The experiments were performed in triplicate on three different days (Equations of the straight lines of the samples: E. edulis pulp, $\mathrm{y}=70.5 \mathrm{x}+8.83, \mathrm{R}^{2}=0.99$; $\mathrm{BHT}$, $\mathrm{y}=95.4 \mathrm{x}+7.88, \mathrm{R}^{2}=0.99 ; \mathrm{TBHQ}, \mathrm{y}=179.9 \mathrm{x}+3.81$, $\mathrm{R}^{2}=0.99$; and quercetin, $\mathrm{y}=299.6 \mathrm{x}+1.86, \mathrm{R}^{2}=0.99$ ).

\section{Quantification of total polyphenols}

The total polyphenols were quantified using the Folin-Ciocalteu reaction, as described by Souza et al. (2007) with the modifications described by Mariani et al. (2013). A calibration curve with a gallic acid standard was used (10 to $300 \mu \mathrm{g} / \mathrm{mL}$ ). The total polyphenols were quantified using the equation of the straight line of the calibration curve, $\mathrm{y}=0.0009 \mathrm{x}+0.0021$ and $\mathrm{R}^{2}=0.96$. The results are expressed as $\mathrm{mg}$ of gallic acid equivalents (EAG) per g of sample. All the analyses were performed in triplicate.

\section{Determination of total anthocyanins}

The total monomeric anthocyanin content of E. edulis fruit pulp was determined by the differential 
pH method described by Giusti and Wrosltad (2001). The final absorbance and the total content of anthocyanins were calculated using the following equations: Final Absorbance $=\left(\mathrm{A}_{520} \mathrm{~nm}-\mathrm{A}_{700} \mathrm{~nm}\right)$ at $\mathrm{pH} 1-\left(\mathrm{A}_{520} \mathrm{~nm}-\mathrm{A}_{700} \mathrm{~nm}\right)$ at $\mathrm{pH} 4.5$ and Total anthocyanin content $=(\mathrm{A} \times \mathrm{MM} \times \mathrm{FD} \times 1000) /(\varepsilon \times 1)$, respectively.

In these equations, $\mathrm{A}=$ final absorbance, $\mathrm{MM}=$ molecular mass, $\mathrm{FD}=$ dilution factor, $1000=$ conversion of grams to milligrams, $1=$ optical path length in centimeters and $\varepsilon=26900$ [molar extinction coefficient in $\mathrm{L} / \mathrm{mol} / \mathrm{cm}$ for cyanidin-3-glycoside (C3G)]. The results are expressed as $\mathrm{mg}$ of $\mathrm{C} 3 \mathrm{G} / 100 \mathrm{~g}$ of dry pulp. The analyses were performed in triplicate.

\section{In vivo evaluation of the nephroprotective activity of $E$. edulis pulp}

Seventy adult mice (Swiss mice, males, weighing 25-40 g) were used. The animals were obtained from the Laboratory of Experimental Monitoring of the University of Vila Velha (UVV), in Espírito Santo, Brazil. The animals were fed a diet of feed and water and maintained at an average temperature of $22^{\circ} \mathrm{C}$ with a 12 -h light/12-h dark cycle.

The research was approved by the Committee on Ethics regarding the Use of Animals (CEUA-UVV; protocol \# 268/2013).

Prior to the induction of NIC, the animals were subjected to five days of gavage treatment with E. edulis pulp at doses of $100 \mathrm{mg} / \mathrm{kg}, 200 \mathrm{mg} / \mathrm{kg}$ and $400 \mathrm{mg} / \mathrm{kg}$. In addition to the synthetic antioxidant $N$-acetylcysteine (NAC) at $100 \mathrm{mg} / \mathrm{kg}$, all the samples were diluted in aqueous solution to a concentration of $50 \mathrm{mg} / \mathrm{mL}$. After 16 hours of water fasting, the synthesis of prostanoids and nitric oxide were inhibited through the administration of indomethacin $(10 \mathrm{mg} / \mathrm{kg}$, dissolved in dimethyl sulfoxide, ip) and L-NAME $(10 \mathrm{mg} / \mathrm{kg}$, dissolved in $0.9 \%$ saline, ip), respectively, and 15 minutes later, NIC was induced through the injection of the second-generation radiological contrast ioversol, which has and low osmolarity (Optiray 320 Mallinckrodt Medical, Inc., St. Louis, MO, USA, $1.5 \mathrm{~g}$ iodine $/ \mathrm{kg}$ ). After 24 hours, the animals were euthanized through the administration of thiopental $(200 \mathrm{mg} / \mathrm{kg}$, ip). Venous blood was collected from the left ventricle for biochemical measurements of urea and creatinine (Billings et al., 2008; Gomes et al., 2014), and the kidneys were removed for histological analysis. These procedures were adapted from protocols previously validated in mice by Lee et al. (2006) and Billings et al. (2008). The animals used in the evaluation were randomly divided into seven groups (each with $\mathrm{n}=7$ ). The control groups were the following: negative control $(\mathrm{CN})$ group, which was administered only water during the treatment; EE400WT group, which was treated with $400 \mathrm{mg} / \mathrm{kg}$ E. edulis pulp and not administered the agent to induce NIC; NIC group, which was pretreated with water; and the positive control (NAC) group, which was administered $100 \mathrm{mg} / \mathrm{kg} \mathrm{N}$-acetylcysteine + NIC. The treated groups were the following: EE100 group, which was administered $100 \mathrm{mg} / \mathrm{kg}$ E. edulis pulp + NIC; EE200 group, which was administered $200 \mathrm{mg} / \mathrm{kg}$ E. edulis pulp + NIC; and EE400 group, which was administered $400 \mathrm{mg} / \mathrm{kg} \mathrm{E}$. edulis pulp + NIC.

\section{Cross-linking protein products containing dityrosine (AOPP)}

Dityrosine-containing cross-linked protein products, which are referred to as AOPPs, are hypochlorous acid $(\mathrm{HClO})$ products induced by amine chlorination. AOPPs was evaluated as described by Witko-Sarsat et al. (1996) with some modifications. Specifically, samples consisting of $200 \mathrm{mg}$ of renal tissue to $1 \mathrm{ml}$ of PBS were prepared. After homogenization, the samples were centrifuged, and the supernatant was separated for use as a protein source. To obtain the standard curve, chloramine T solution (0 to $100 \mu \mathrm{mol} / \mathrm{L}$ ), was added to each well of a 96-well microtiter plate (Becton Dickinson Labware, Lincoln Park, NJ, USA), and $10 \mu \mathrm{L}$ of 1 and $16 \mathrm{~mol} / \mathrm{L}$ potassium iodide (KI) and $20 \mu \mathrm{L}$ of glacial acetic acid were added. The absorbance of the reaction mixture was immediately read at a wavelength of $340 \mathrm{~nm}$ and compared with that of the blank, which consisted of $200 \mu \mathrm{L}$ of PBS, $10 \mu \mathrm{L}$ of KI and $20 \mu \mathrm{L}$ of acetic acid. The absorbance of chloramine $\mathrm{T}$ at a wavelength of $340 \mathrm{~nm}$ was linear within the range of 0 to $100 \mu \mathrm{mol} / \mathrm{L}$ (Line equation: $\mathrm{y}=0.1288 \mathrm{x}+0.1658$ with $\left.\mathrm{R}^{2}=0.98\right)$. The AOPP concentrations were determined when the correlation coefficient was greater than 0.95 and are expressed as $\mu \mathrm{mol} / \mathrm{mg}$ total protein, where the total protein was previously quantified using the Bradford method (Bradford, 1976). The equation of the line was $\mathrm{y}=0.6491 \mathrm{x}+0.0118\left(\mathrm{R}^{2}=0.98\right)$.

\section{Determination of acute toxicity ( $\left.\operatorname{LD}_{50}\right)$}

The oral toxicity was assessed using protocol 423 recommended by OECD-423/2001 "Acute Toxicity of Class" (OECD, 2001), which determines the doses to be used in the study. In the present study, the maximum dose of E. edulis lyophilized pulp (per gavage in a single dose) used in the protocol, $2000 \mathrm{mg} / \mathrm{kg}$ (based on data from previous studies with other species of this plant 
(Ribeiro, Seravalli, 2007), was administered directly to the treated group, and purified water was administered to the control group. Three female Swiss mice (nulliparous, nonpregnant, and weighing between 20 and $35 \mathrm{~g}$ ) were included in each group. The toxicological category was estimated according to the specifications of the protocol, and the experiment was performed in duplicate.

\section{Histological analysis}

For histopathological examination, the kidneys were preserved in $10 \%$ formaldehyde, and the liver was preserved in Bouin's fixative solution. The samples were maintained in $70 \%$ alcohol until preparation of the histological sections and then contrasted with hematoxylin and eosin (HE). The tissues were embedded in paraffin and sectioned at $4 \mathrm{~mm}$ (Mattos et al., 2009).

The slides were qualitatively analyzed through optical microscopy by an experienced pathologist. All the cuts were blindly examined (Billings et al., 2008).

\section{Statistical analyses}

The values obtained from the biological evaluations are expressed as the means \pm standard deviations of the mean (EPMs), and the values obtained from the chemical evaluations are expressed as the means \pm standard deviations (DPs). These values were then analyzed by oneway analysis of variance (ANOVA) followed by Tukey's post hoc text, with $p<0.05$. The correlation coefficient of the standard curves was obtained through linear regression using the least squares method, and the data were also analyzed by ANOVA with a 95\% LC and n-1 degrees of freedom. The limits of detection (LD) and quantification (LQ) were calculated by dividing the standard deviation of the linear coefficients of the calibration curves generated in the assays. Excel (Microsoft Office 2010) and Prism software (Prism 6, GraphPad Software, Inc., San Diego, CA, USA) were used.

\section{RESULTS}

\section{Evaluation of the antioxidant capacity of $E$. edulis pulp}

According to DPPH method, which was performed as described by Scherer and Godoy (2009), the antioxidant activity index (AAI) of E. edulis pulp was 3.4, and the $\mathrm{CI}_{50}$ was $11.4 \mu \mathrm{g} / \mathrm{mL}$. Ferulic acid had an AAI of 5.49 and a $\mathrm{CI}_{50}$ of $7.12 \mu \mathrm{g} / \mathrm{mL}$, and the $\mathrm{R}^{2}$ of the assay was 0.994 .
The antioxidant capacity of the tested compounds, as determined based on the inhibition of the ABTS cation radical, could be ranked in the following order: quercetin $(0.16 \pm 0.005 \mathrm{mg} / \mathrm{mL})>\mathrm{TBHQ}(0.25 \pm 0.005 \mathrm{mg} / \mathrm{mL})>$ BHT $(0.44 \pm 0.1 \mathrm{mg} / \mathrm{mL})>$ E. edulis pulp $(0.59 \pm 0.03 \mathrm{mg} / \mathrm{mL})$.

\section{Quantification of total polyphenols and anthocyanins}

The total polyphenol content of lyophilized E. edulis was $811 \pm 16.7 \mathrm{mg} \mathrm{EAG/g}$ ), and in the present study, the monomeric anthocyanins were quantified using the differential $\mathrm{pH}$ method, which revealed a content of $181.25 \pm 5.36 \mathrm{C} 3 \mathrm{G} \mathrm{mg} / 100 \mathrm{~g}$.

\section{In vivo evaluation of the nephroprotective activity of $E$. edulis pulp based on the creatinine and urea levels}

The present study constitutes the first investigation of the effects of $E$. edulis pulp on both renal function and structure in response to oxidative stress in mice with radiological contrast-induced nephrotoxicity.

In the present study, the serum creatinine levels of the NIC group $(0.60 \pm 0.14 \mathrm{mg} / \mathrm{dl})$ were increased compared with those of the control group $(0.14 \pm 0.01 \mathrm{mg} / \mathrm{dL})$, and this increase in creatinine content was greater than $25 \%$. No difference was found between the control group $(0.14 \pm 0.01 \mathrm{mg} / \mathrm{dL})$ and the $400 \mathrm{mg} / \mathrm{kg}$ E. edulis group $(0.17 \pm 0.0 \mathrm{mg} / \mathrm{dL})$. The animals treated with $E$. edulis pulp at concentrations of $100 \mathrm{mg} / \mathrm{kg}(0.27 \pm 0.02 \mathrm{mg} / \mathrm{dL})$, $200 \mathrm{mg} / \mathrm{dL}(0.34 \pm 0,10 \mathrm{mg} / \mathrm{dl})$ and $400 \mathrm{mg} / \mathrm{dL}$ $(0.38 \pm 0.09 \mathrm{mg} / \mathrm{dL})$ presented creatinine levels close to those of the control animals $(0.14 \pm 0.01 \mathrm{mg} / \mathrm{dL})$ and the animals in the $\mathrm{N}$-acetylcysteine-treated group $(0 . .1 \pm 0.00 \mathrm{mg} / \mathrm{dL})$, but their levels were not different from those of the animals in the NIC group $(0.60 \pm 0.14 \mathrm{mg} / \mathrm{dL})$ (Figure 1).

The serum values of urea in the animals that received $100 \mathrm{mg} / \mathrm{kg}$ E. edulis $(93 \pm 0.6 \mathrm{mg} / \mathrm{dL})$ pulp prior to the induction of contrast nephropathy were similar to those of the control group $(71 \pm 2.8 \mathrm{mg} / \mathrm{dL})$. E. edulis pulp at a dose of $100 \mathrm{mg} / \mathrm{kg}$ yielded superior renal protection to treatment with $\mathrm{N}$-acetylcysteine $(226 \pm 9.3 \mathrm{mg} / \mathrm{dL})$, as indicated by urea values after the induction nephropathy similar to those found for the NIC group $(256 \pm 21 \mathrm{mg} / \mathrm{dL})$. No difference was found between the groups administered the highest dosages of E. edulis pulp, $200 \mathrm{mg} / \mathrm{dl}(237 \pm 48 \mathrm{mg} / \mathrm{dL})$ and $400 \mathrm{mg} / \mathrm{dl}(323 \pm 40 \mathrm{mg} / \mathrm{dL})$, and the NIC group (Figure 2). 


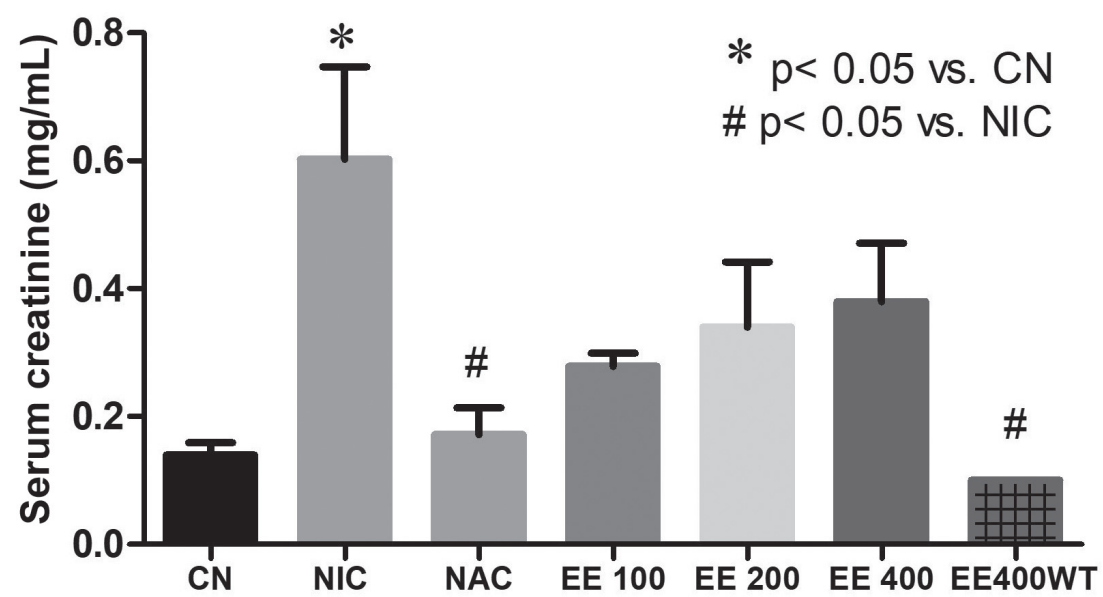

FIGURE 1 - Serum creatinine level in mice treated for 5 days before the induction of NIC. Groups: CN, negative control; NIC, contrast nephropathy; NAC, $100 \mathrm{mg} / \mathrm{kg}$-acetylcysteine; EE100, $100 \mathrm{mg} / \mathrm{kg}$ E. edulis + NIC; EE200, $200 \mathrm{mg} / \mathrm{kg}$ E. edulis + NIC; EE400, $400 \mathrm{mg} / \mathrm{kg}$ E. edulis + NIC; and EE400WT, control $400 \mathrm{mg} / \mathrm{kg}$ E. edulis.

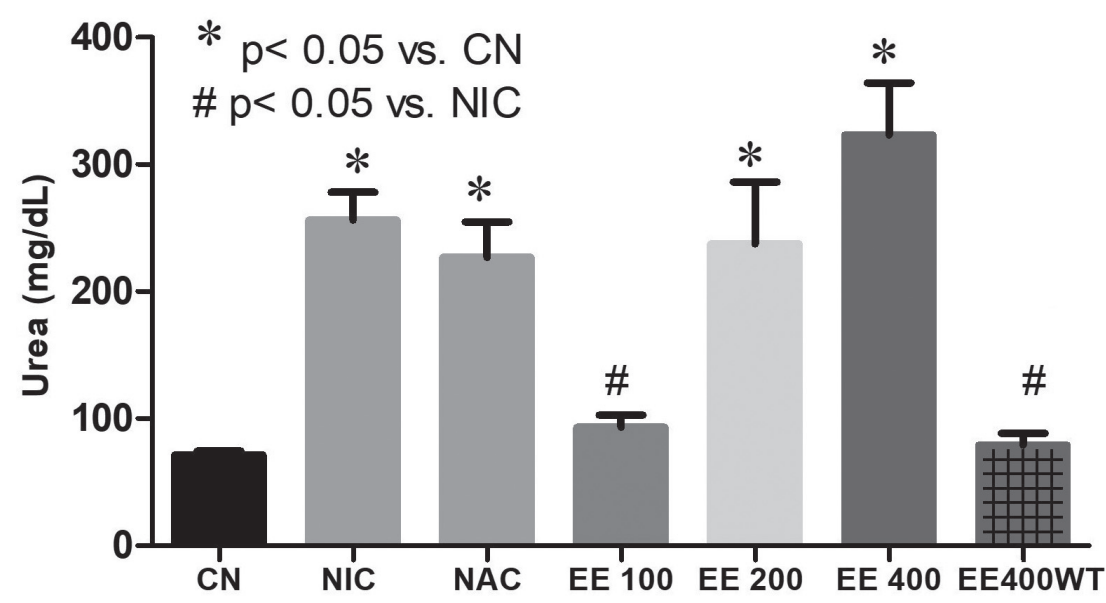

FIGURE 2 - Serum urea level in mice treated for 5 days before the induction of NIC. Groups: CN, negative control; NIC, contrast nephropathy; NAC, $100 \mathrm{mg} / \mathrm{kg} \mathrm{N}$-acetylcysteine; EE100, $100 \mathrm{mg} / \mathrm{kg}$ E. edulis + NIC; EE200, $200 \mathrm{mg} / \mathrm{kg}$ E. edulis + NIC; EE400, $400 \mathrm{mg} / \mathrm{kg}$ E. edulis + NIC; and EE400WT, control $400 \mathrm{mg} / \mathrm{kg}$ E. edulis.

\section{Cross-linking protein products containing dityrosine (AOPPs)}

In the present study, the degree of protein oxidation of the animals belonging to the NIC group $(0.27 \pm 0.01 \mu \mathrm{mol} / \mathrm{mg})$ was increased compared with the control group $(0.16 \pm 0.0 \mu \mathrm{mol} / \mathrm{mg})$. The animals treated with $E$. edulis pulp at concentrations of $100 \mathrm{mg} / \mathrm{kg}(0.21 \pm 0.02 \mu \mathrm{mol} / \mathrm{mg})$ and $200 \mathrm{mg} / \mathrm{dL}$ $(0.27 \pm 0.09 \mu \mathrm{mol} / \mathrm{mg})$ showed a similar AOPP level to the control animals and to the group treated with NAC, which represents the conventional treatment $(0.25 \pm 0.01 \mu \mathrm{mol} / \mathrm{mg})$. Only the group treated with $400 \mathrm{mg}$ E. edulis $(0.35 \pm 0.07 \mu \mathrm{mol} / \mathrm{mg})$ presented elevated protein oxidation compared with the control animals. The group that received only E. edulis pulp presented AOPP values equal to those of the control group (Figure 3 ).

\section{Histological analysis}

The histological analysis of the kidneys collected from the animals belonging to the NIC group showed vacuolar degeneration and cortical vacuolization (Figure 4B, I, P). These lesions were not observed in any of the CN (Figure 4A, H, O) or EE400WT (Figure 4D, $\mathrm{K}, \mathrm{R}$ ) slides, which showed renal cells with a preserved renal architecture.

The animals that received $100 \mathrm{mg} / \mathrm{kg}$ E. edulis pulp (Figure 4E, L, S) and $\mathrm{N}$-acetylcysteine (Figure 4C, J, Q) presented better preserved renal cell structures with a normal tubular and glomerular appearance without pathological findings. However, the toxicity caused by the iodate contrast agent was increased in the animals administered $200 \mathrm{mg} / \mathrm{kg}$ (Figure 4F, M, T) and $400 \mathrm{mg} / \mathrm{kg}$ E. edulis (Figure $4 \mathrm{G}, \mathrm{N}, \mathrm{U}$ ). In these laminae, discrete to 


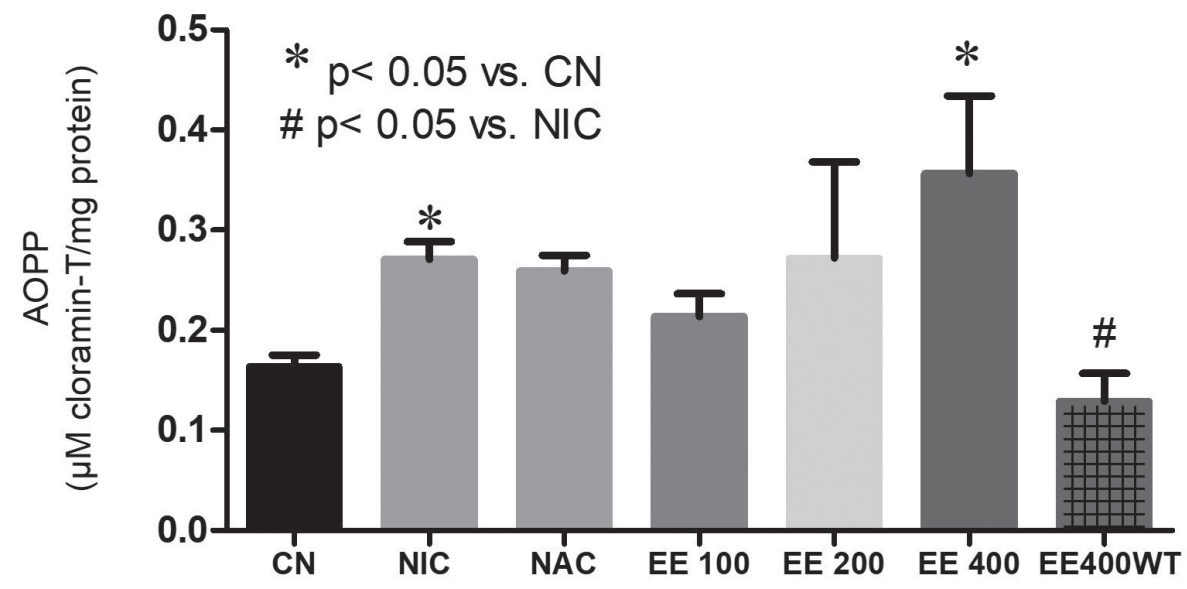

FIGURE 3 - AOPP level of mice treated for 5 days prior to the induction of NIC. Groups: CN, negative control; NIC, contrast nephropathy, NAC, $100 \mathrm{mg} / \mathrm{kg} N$-acetylcysteine; EE100, $100 \mathrm{mg} / \mathrm{kg}$ E. edulis + NIC; EE200, $200 \mathrm{mg} / \mathrm{kg}$ E. edulis + NIC; EE400, $400 \mathrm{mg} / \mathrm{kg}$ E. edulis + NIC; and EE400WT, control $400 \mathrm{mg} / \mathrm{kg}$ E. edulis.

intense vacuolar degeneration, the presence of perivascular and inflammatory infiltrates, and dilation of the proximal tubule were observed (Figure 4).

\section{Determination of acute toxicity $\left(\mathrm{LD}_{50}\right)$}

Considering the results of the biochemical analyses performed in the present study, which demonstrated that E. edulis pulp does not exert toxic effects at a dose lower than $400 \mathrm{mg} / \mathrm{kg}$ in the absence of radiocontrast, we started the $\mathrm{LD}_{50}$ protocol with a dose of $2000 \mathrm{mg} / \mathrm{kg}$. No morbidity or mortality was recorded in the evaluated groups, which confirms that E. edulis pulp exhibits acute oral toxicity at a dose higher than $2000 \mathrm{mg} / \mathrm{kg}$ and classifies this fruit as category 5 according to the criteria of the experimental protocol adopted (OECD, 2001). The histological analysis of the renal and hepatic tissues revealed no pathological findings in either organ.

The biochemical results from the determination of renal and hepatic function markers showed no difference between the groups treated with E. edulis pulp and the control group, with the exception of the creatinine level (Table I).

\section{DISCUSSION}

\section{Evaluation of the antioxidant capacity of $E$. edulis pulp}

The results of the present study provide the first demonstration of the renal protective effect of E. edulis pulp, and the mechanism of action likely involves the antioxidant effect of polyphenolic substances and resulting in decreased renal dysfunction and

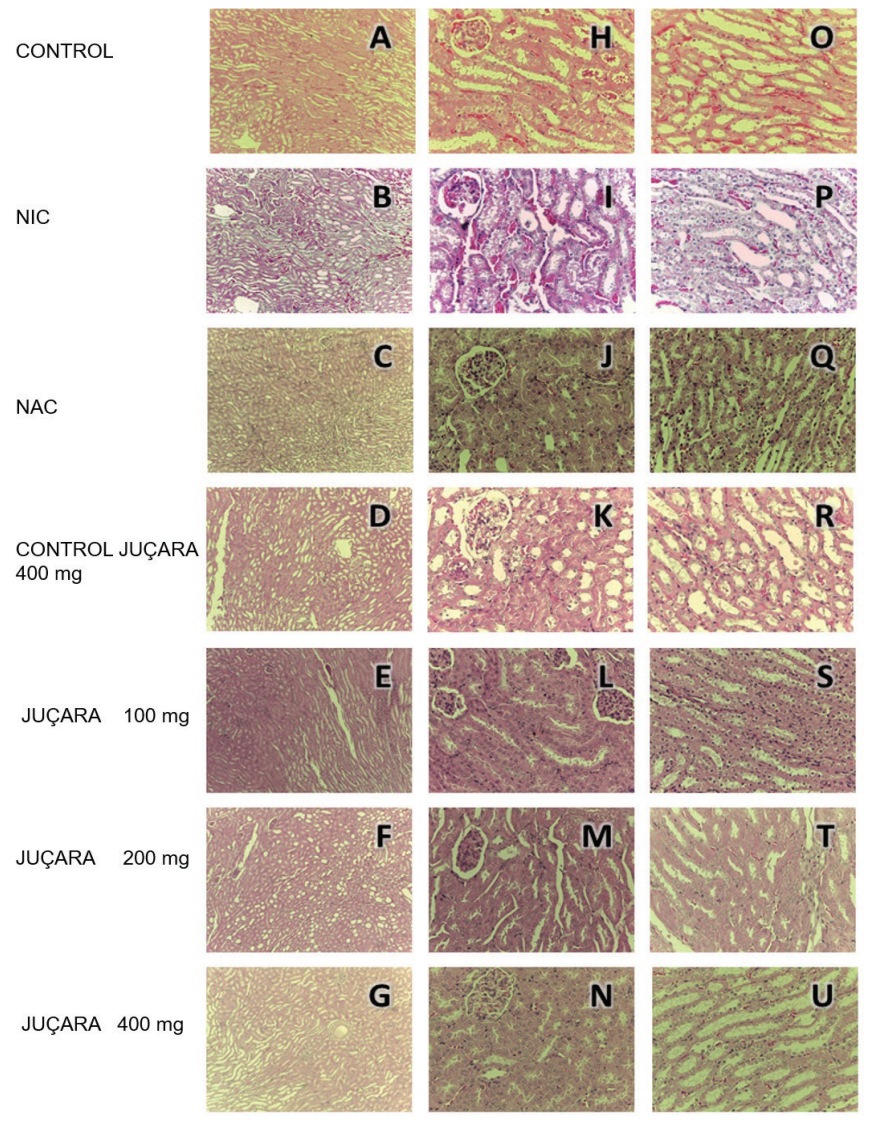

FIGURE 4 - Representative micrographs showing the renal histology of the mice after the induction of NIC. Groups: CN, negative control; NIC, contrast nephropathy; NAC, $100 \mathrm{mg} / \mathrm{kg}$ $\mathrm{N}$-acetylcysteine; EE100, $100 \mathrm{mg} / \mathrm{kg}$ E. edulis + NIC; EE200, $200 \mathrm{mg} / \mathrm{kg}$ E. edulis + NIC; EE400, $400 \mathrm{mg} / \mathrm{kg}$ E. edulis + NIC; and EE400WT, control $400 \mathrm{mg} / \mathrm{kg}$ E. edulis. Images A to $\mathrm{G}$ : cortex-medulla section $(100 \mathrm{x})$, demonstrating changes in the typical renal architecture; Images $\mathrm{H}$ to $\mathrm{N}$ : cortical region (400x); and images $\mathrm{O}$ to $\mathrm{U}$ : medulla region (400x) showing tubulointerstitial lesions. 
TABLE I - Biochemical results of renal and hepatic acute toxicity of animals treated with $2,000 \mathrm{mg} / \mathrm{kg}$ of E. edulis $(\mathrm{T})$ and control (C) pulps

\begin{tabular}{lcc}
\hline $\begin{array}{l}\text { Biochemical } \\
\text { target }\end{array}$ & Groups & $\begin{array}{c}\text { Average } \\
\text { (mg/dL) } \pm \text { standard error }\end{array}$ \\
\hline \multirow{2}{*}{ AST } & $\mathrm{C}$ & $239 \pm 67.5$ \\
& $\mathrm{~T}$ & $204 \pm 34.5$ \\
FA & $\mathrm{C}$ & $176 \pm 44.7$ \\
& $\mathrm{~T}$ & $89.2 \pm 10.3$ \\
GGT & $\mathrm{C}$ & $3.83 \pm 0.87$ \\
& $\mathrm{~T}$ & $2.6 \pm 0.67$ \\
Urea & $\mathrm{C}$ & $41.1 \pm 1.93$ \\
& $\mathrm{~T}$ & $49.6 \pm 5.75$ \\
Creatinine & $\mathrm{C}$ & $0.23 \pm 0.03$ \\
& $\mathrm{~T}$ & $0.36 \pm 0.03 *$ \\
Total protein & $\mathrm{C}$ & $5.51 \pm 0.44$ \\
& $\mathrm{~T}$ & $5.16 \pm 0.36$ \\
Albumine & $\mathrm{C}$ & $1.93 \pm 0.11$ \\
\hline
\end{tabular}

morphological tubular lesions in mice after the induction of NIC.

The E. edulis fruit is considered a source of polyphenols and anthocyanins, and the antioxidant activity of an extract or fruit pulp, as previously discussed by several authors, is directly associated with the amount of these compounds present in the chemical composition (Vedana et al.,2008; Silva et al., 2010; Koolen et al., 2013; Silva et al., 2013).

The results obtained with the DPPH method indicated a very strong AAI of 3.4 and a $\mathrm{CI}_{50}$ of $11.4 \mu \mathrm{g} / \mathrm{mL}$, which suggests that $E$. edulis pulp exhibits antioxidant activity under the conditions used in this experiment. In addition, these values are close to those obtained in this study for ferulic acid (AAI $=5.49$ and $\mathrm{CI}_{50}=7.12 \mu \mathrm{g} / \mathrm{mL}$ ), demonstrating the antioxidant potential of $E$. edulis.

Using the ABTS method, the $\mathrm{CI}_{50}$ of E. edulis pulp was compared with the concentrations obtained for the standard solutions (BHT, TBHQ and quercetin), and significant $(\mathrm{p}<0.05)$ differences were found in all pairwise comparisons. In addition, if a product has a higher antioxidant potential, a lower concentration is required for the inhibition of free radicals (Stajčić et al., 2012). It should be noted that the observed $\mathrm{CI}_{50}$ of E. edulis pulp, which is a nonconcentrated product from the edible part of the fruit, is similar to the values obtained for the synthetic antioxidants BHT, TBHQ and quercetin, which are compounds with known antioxidant activity (Silva, Jorge, 2011; Wang et al., 2008; Scherer, Godoy, 2009).

\section{Quantification of total polyphenols and anthocyanins}

The antioxidant activity obtained in this study might be related to the high content of total polyphenols found in lyophilized E. edulis pulp $(811 \pm 16.7 \mathrm{mg} \mathrm{EAG/g})$. Borges et al. (2011b) reported values ranging from 303.63 to $806.37 \mathrm{mg}$ EAG/g for fresh $E$. edulis pulp obtained after extraction using different variables. Bicudo et al. (2014) performed experiments with E. edulis fruit collected at different stages of maturation and reported total polyphenol concentrations ranging from 49.09 to $81.69 \mathrm{mg}$ $\mathrm{EAG} / \mathrm{g}$, which are substantially lower than those obtained in this study. It is known that the polyphenol content in E. edulis pulp is highly influenced by environmental, climatic and fruit maturation factors (Borges et al., 2011a; Bicudo, Ribani, Beta, 2014) as well as the extraction time and solvents used (Borges et al., 2011b).

Other studies have also reported levels of anthocyanins near the concentration range observed in the fruit of the E. edulis palm tree. Ribeiro et al. (2011) reported an anthocyanin content of $148.67 \mathrm{mg} / 100 \mathrm{~g}$ in fruits collected in the state of Rio de Janeiro (Brazil), and Borges et al. (2011a) reported anthocyanin levels ranging from 14,84 to $409,85 \mathrm{mg} / 100 \mathrm{~g}$ in fruits collected from different regions in the state of Santa Catarina (Brazil) with different climatic conditions. Brito et al. (2007) obtained a content of $290 \mathrm{mg} / 100 \mathrm{~g}$ from fruits collected in the state of São Paulo (Brazil). In addition, Borges et al. (2011a) noted that the fruits of palms grown in the summer months, during a common fruiting period and at medium altitude have a higher anthocyanin content than fruits obtained from other regions; thus, these researchers concluded that a higher incidence of solar radiation on the fruits has a positive effect on anthocyanin synthesis and that the solar intensity affects the metabolism and synthesis of flavonoids in general and promotes a greater accumulation of anthocyanins. The fruits of $E$. edulis used in this research were cultivated at an altitude of $70 \mathrm{~m}$ and collected in the Brazilian winter (August), which could explain the anthocyanin content obtained in the study.

\section{In vivo evaluation of the nephroprotective activity of $E$. edulis pulp based on the creatinine and urea levels}

In the present study, the mice were administered 
contrast medium at a dose similar to that used clinically $(1.5 \mathrm{~g} / \mathrm{kg}$ iodine in routine angiographic practice). Prostaglandin and NO syntheses were also inhibited to simulate the clinical situations that predispose patients to NIC, which result in increases in oxidative stress, reductions in the renal blood flow, and thereby vasoconstriction and hypoxia (Selistre et al., 2015; Kongkham, Sriwong, Tasanarong, 2013). However, analysis of the creatinine and urea dosage of the NIC and $\mathrm{CN}$ groups verified the presence of azotemia with a significant elevation of these nitrogen compounds (Figure 1 and 2). Other investigations have also reported an experimental model of NIC characterized by an elevation of the serum creatinine level of $\geq 25 \%$ in rats and mice (Billings et al., 2008; Lee et al., 2006). No difference in the creatinine and serum urea levels were found between the $\mathrm{CN}$ and EE400WT groups, indicating that under nonpathological conditions, E. edulis pulp does not induce nephropathy.

The animals of the EE100, EE200 and EE400 groups presented serum creatinine levels equal to those of the $\mathrm{CN}$ and NAC groups (Figure 1). Because the induction of NIC elevated the creatinine level by more than $25 \%$, as determined through a comparison of the NIC and CN groups, these data show that although the groups treated with E. edulis pulp cannot be differentiated from the NIC group based on the creatinine level, this treatment tended to provide renal protection with a possible reduction of damage due to glomerular filtration. However, under these experimental conditions, the group treated with $\mathrm{N}$-acetylcysteine, which forms part of the prophylactic regimen that is currently used, showed better results (Pattharanitima, Tasanarong, 2014; McCullough, Akrawinthawong, 2013).

The urea level was also analyzed (Figure 2), and the serum values of urea in the animals that received $100 \mathrm{mg} / \mathrm{kg} \mathrm{E}$. edulis pulp suggest that E. edulis provided renal protection against some deleterious mechanisms associated with glomerular filtration after the induction of NIC. The animals treated with $100 \mathrm{mg} /$ $\mathrm{kg}$ E. edulis pulp had lower urea levels than the NAC group, which curiously showed values similar to those found in the NIC group. Selistre et al. (2015) studied the importance of urea in the differential diagnosis of acute renal failure and stated that one of the criteria for diagnosing acute kidney injury is the absolute increase in the serum creatinine level. The EE200 and EE400 groups did not differ from the NIC group, and thus, a possible protective effect of the pulp at high doses can be ruled out.

\section{Cross-linking protein products containing dityrosine (AOPP)}

The AOPP analysis revealed oxidative stress in the renal tissue of animals after the induction of contrast nephropathy (Figure 3). AOPPs are a group of protein products generated by proteins with hypochlorous acid and chloramines in response to oxidative stress (Colombo et al., 2015). These oxidants are produced by the myeloperoxidase released by activated neutrophils in response to an imbalance in the antioxidant mechanisms, and as a consequence, these free radicals act on proteins to produce dityrosine (Piowowar, 2010).

The animals with induced NIC that were previously treated with the lowest doses of E. edulis pulp presented AOPP levels similar to those of the control animals. These data reinforce the fact that the treatment provided some protection to the animals because contrast nephropathy caused a significant elevation of the level of AOPPs in the NIC group. However, the EE400 group presented a marked increase in AOPPs, suggesting that this dosage does not provide any renal protection and raising the possibility of a possible synergetic pro-oxidant effect of $E$. edulis at a high dose.

The AOPP evaluation performed in this experiment confirms that although the animals treated with the lowest doses of E. edulis could not be differentiated from the NIC group, E. edulis pulp tended to provide renal protection in animals with induced contrast nephropathy through the antioxidant activity of the polyphenols in the pulp.

\section{Histological analysis}

In the representative micrographs showing the renal histology of the different groups of mice (Figure 4), it is possible to observe that the animals of the NIC group presented typical lesions of contrast nephropathy in proximal tubular cells. Pathological changes, such as vacuolar degeneration, intense vacuolization of proximal tubular cells and balloonization, were also described by Eduardo-Carraro et al. (2016) and Yokomaku et al. (2008), who studied rats with induced nephropathy. Therefore, in addition to the above-described biochemical parameters, our histopathological data indicate a significant disturbance of the renal structure in the NIC group in comparison with the control animals, which is in agreement with other studies (Billings et al. 2008; Yokomaku et al., 2008; Khan et al., 2013).

In this experiment, tubular necrosis, which was described by Yokomaku et al. (2008) and Billings et al. (2008), was not observed. However, nephropathy can 
occur within a period of 24-72 hours (Andreucci et al., 2014), and in the present research, the animals were euthanized within 24 hours. Therefore, there was no time for the ischemia to cause irreversible lesions, such as acute tubular necrosis, and thus, only vacuolar degeneration was detected.

Two mechanisms for the induction of nephropathy by iodinated contrast have been proposed: ischemia injury and direct tubular damage. Both mechanisms lead to a decrease in the glomerular filtration rate, indicating the initiation of acute renal injury (LRA) (Caiazza et al., 2013). In ischemic lesions, the generated vasoconstriction leads to subsequent hypoxia, which causes endothelial damage through the production of reactive oxygen species (EROS), and this damage, in turn, directly injures the renal tubules and the vascular endothelium. EROS can also react with the nitric oxide present in the endothelium to form peroxynitrite, a highly harmful oxidant. The deposition of contrast in the renal tubules directly causes tubular damage, leading to cytotoxicity (Andreucci et al., 2014). According to Bucher et al. (2014), an increase in contrastinduced osmolarity is a secondary event to the occurrence of cytoplasmic vacuolation in proximal tubular cells, and Martín et al. (2014) assessed the direct toxic effect of contrasting media on tubular epithelial cells, which results in disturbances to the hemodynamics of renal blood flow.

The histological analysis of the kidneys collected from the EE100 and NAC groups demonstrated better preserved cellular structures, which suggests that similar to treatment with $N$-acetylcysteine, $100 \mathrm{mg} / \mathrm{kg}$ E. edulis pulp, which is rich in polyphenols, provides protection to renal tissue and is capable of combating free radicals generated by oxidative stress in contrast nephropathy. It is known that juçara is rich in polyphenols (Paredes-López et al., 2010; Borges et al., 2011a; Inácio et al., 2013; Bicudo, Ribani, Beta, 2014) and that these antioxidant compounds are able to stabilize or deactivate free radicals before they attack their biological targets in cells (Ribeiro et al.,2010). The increased toxicity caused by iodate contrast detected in the animals that received the higher doses of E. edulis pulp suggests that juçara pulp loses its protective effect on renal tissue at a dose higher than $200 \mathrm{mg} / \mathrm{kg}$.

\section{Determination of acute toxicity $\left(\operatorname{LD}_{50}\right)$}

Acute toxicity was estimated to be induced by doses higher than $2000 \mathrm{mg} / \mathrm{kg}$, and this fruit was classified as category 5 according to protocol OECD 423 (2011), which indicates that it is a relatively low acute toxicity hazard. These results indicate that there is a safety margin for the use of E. edulis pulp as a therapeutic agent, although additional toxicological studies are still required. Acute toxicity is defined as adverse effects occurring within a short time (24 hours) after administration of a single or multiple doses (Oga, Camargo, Batistuzzo, 2008).

As shown in Table I, no differences in biochemical parameters were found between the control group and the $2000 \mathrm{mg} / \mathrm{kg}$ E. edulis-treated group. The creatinine levels revealed a difference between the treated and controls, reinforcing the hypothesis that at doses higher than 400 $\mathrm{mg} / \mathrm{kg}$, E. edulis pulp can exert a possible pro-oxidant effect.

\section{CONCLUSION}

Under the conditions used in this experiment, we conclude that at low doses, E. edulis pulp tends to provide protection against the development of renal dysfunction in mice with induced contrast nephropathy. However, $\mathrm{N}$-acetylcysteine showed better results. In addition, E. edulis pulp, which is enriched in polyphenols, particularly anthocyanins, markedly reduced the incidence of glomerular and renal tubular lesions. Further studies are needed to better elucidate the efficacy of E. edulis pulp in the prevention of NIC.

\section{ACKNOWLEDGMENTS}

The authors thank the Foundation for Support to Research and Innovation of Espírito Santo (FAPES; process - 65835131/0010-2013, TO \# 241/2016), SEAG/ FAPES (TO \# 665/2016) and CNPq (PQ- process \# $310680 / 2016-6)$ for the funding provided. The authors also acknowledge the Laboratory of Sanitation (UFES) and Instituto Tommasi for allowing use of their equipment and UVV for the financial support provided.

\section{REFERENCES}

Andreucci M, Faga T, Pisani A, Sabbatini M, Michael A. Acute kidney injury by radiographic contrast media: pathogenesis and prevention. Biomed Res Int. 2014;2014:362725.

Bicudo MO, Ribani RH, Beta T. Anthocyanins, phenolic acids and antioxidant properties of Juçara fruits (Euterpe edulis M.) along the on-tree ripening process.Plant Foods Hum Nutr. 2014;69(2):142-147.

Billings FT, Chen SW, Kim M, Park SW, Song JH, Wang S, et al. Alpha2-Adrenergic agonists protect against radiocontrastinduced nephropathy in mice. Am JPhysiol Renal Physiol. 2008;295(3):741-748. 
Borges GSC, Vieira FGK, Copetti C, Gonzaga LV, Zambiase RC, Filho JM.Chemical characterization, bioactive compounds, and antioxidant capacity of jussara (Euterpe edulis) fruit from the Atlantic Forest in Southern Brazil. Food Res Int. 2011a;44(7):2128-2133.

Borges GSC, Vieira FGK, Copetti C, Gonzaga LV,Fett R. Optimization of the extraction of flavanols and anthocyanins from the fruit pulp of Euterpe edulis using the response surface methodology.Food Res Int. 2011b;44(3):708-715.

Bradfort M. Analytical biochemistry: methods in the biological sciences. 1976;72:248-254.

Brito ES de, Araújo MCP de, Alves RE, Carkeet CC, Clevidence B, Novotny J. Anthocyanins present in selected tropical fruits: Acerola, jambolão, jussara e guarabiju. J Agric Food Chem. 2007;55(23):9389-9394.

Bucher AM, Cecco CN de, Schoepf UJ, Meinel FG, Krazinski $\mathrm{AW}$, Spearman N, et al. Is contrast medium osmolality a causal factor for contrast-induced nephropathy. Biomed Res Int. 2014;2014:931413.

Caiazza A, Russo L, Sabbatini M, Russo D. Hemodynamic and tubular changes induced by contrast media. Biomed Res Int. 2014;2014:578974.

Colombo G, Clerici M, Giustarini D, Portinaro N, Badalamenti $\mathrm{S}$, Rossi R, et al. A central role for intermolecular dityrosine cross-linking of fibrinogen in high molecular weight advanced oxidation protein product (AOPP) formation. Biochim Biophys Acta.2015;1850(1):1-12.

Diogo LP, Bahlis LF, Carvalhal GF. Computerized tomography contrast induced nephropathy (CIN) among adult inpatients. J Braz Nefrol. 2014;36:446-450.

Eduardo-Carraro JCC, Santino MFF, Macedo HW, Silva LE. Impact of gender in early structural changes of contrast induced nephropathy in rats. Braz J Nefrol. 2016;38(4):390-395.

Giusti MM, Wrolstad RE. Anthocyanins: characterization and measurement with uv-visible spectroscopy. In: Wrolstad RE. Current protocols in food analytical chemistry. New York: John Wiley \& Sons. 2001; 1.2.1-13.
Gomes IB, Porto ML, Santos MC, Campagnaro BP, Pereira TM, Meyrelles SS, et al. Renoprotective, anti-oxidative and anti-apoptotic effects of oral low-dose quercetin in the C57BL/6J model of diabetic nephropathy. Lipids Health Dis. 2014;13(184):1-10.

Heyman SN, Rosen S, Khamaisi M, Idée JM, Rosenberger C. Reactive oxygen species and the pathogenesis of radiocontrastinduced nephropathy. Invest Radiol. 2010;45(4):188-195.

Inácio MRC, Lima KMG, Lopes VG, Pessoa JDC, Teixeira GHA. Total anthocyanin content determination in intact açaí (Euterpe oleraceaMart.) and palmitero-juçara (Euterpe edulis Mart.) fruit using near infrared spectroscopy (NIR) and multivariate calibration. Food Chem. 2013;136(3-4):1160-1164.

Kaye DM, Stub D, Mak V, Doan T, Duffy SJ. Reducingiodinatedcontrast volume y manipulating injection pressure during coronaryangiography. Catheter Cardiovasc Interv. 2014;83(5):741-745.

Khan AM, Maderdrut JL, Li M, Toliver HL, Coy DH, Simon EE, Batuman V. Pituitary adenylate cyclase-activating polypeptide prevents contrast-induced nephropathy in a novel mouse model. Physiol Rep. 2013;1(6):1-14.

Kongkham S, Sriwong S, Tasanarong A. Protective effect of alpha tocopherol on contrast-induced nephropathy in rats. Nefrologia. 2013;18(33):116-123.

Koolen HFH, Silva MAF, Gozzo CF, Souza QA, Souza DLA. Antioxidant, antimicrobial activities and characterization of phenolic compounds from buriti (Mauritia flexuosa L. f.) by UPLC-ESI-MS/MS. Food Res Int. 2013;51(2):467-473.

Lee HT, Jan M, Bae SC, Joo JD, Goubaeva FR, Yang J, Kim M. A1 adenosine receptor knockout mice are protected against acute radiocontrast nephropathy in vivo. Am J Physiol Renal Physiol. 2006;290(6):1367-1375.

Magro MCS, Vattimo MFF. Avaliação da função renal: creatinina e outros biomarcadores. Rev Bras Ter Intensiva. 2007;19(2):182-185.

Mariani PM, Freitas PR, Kalil IC, Brasil GA, Ronchi SN, Lenz D. Efectosquimiopreventivos y antimutagénicos in vivo delextractohidroetanólico de frutos de Caricapapaya L. Rev Cuba Plantas Med. 2013;18(3):381-390. 
Martín CM, Lorigados CAB, Kogika MM, Ferrante B, Grunkraut AS, Pinto ACBCF. Nefropatia induzida por contraste iodado. Rev Acad Ciênc Agrár Ambient. 2014;12(4):283-295.

Mattos DPBG, Martorelli RA, Menezes RC, Freire RB, Coelho JMCO, Amendoeira MRR, et al. Histopatologia e imuno-histoquímica de camundongos C57BL/6 infectados por Toxoplasma gondii cepa ME-49 e alimentados com micotoxinas. Rev Bras Ciênc Vet. 2009;16(1):27-32.

Mccullough PA, Akrawinthawong K. Ascorbic acid for the prevention of contrast induced acute kidney injury. J Am Coll Cardiol. 2013;62(23):2176-2177.

OECD Guideline for Testing of Chemicals, Acute Oral ToxicityAcute Toxicity Class Method, 423. Adopted 17th December; 2001.

Oga S, Camargo MMA, Batistuzzo JAO. Fundamentos da Toxicologia. $3^{\mathrm{a}}$ ed. São Paulo: Atheneu; 2008.

Osthoff M, Trendelenburg M. Impact of mannose-binding lectin deficiency on radiocontrast-induced renal dysfunction. Biomed Res Int. 2013;2013:962695.

Paredes-López O, Cervantes-Ceja ML, Vigna-Pérez M, Hernández-Perez T. Berries: improving human health and healthy aging, and promoting quality life: a review. Plant Foods Hum Nutr. 2010;65(3):299-308.

Pattharanitima P, Tasanarong A. Pharmacological strategies to prevent contrast induced acute kidney injury. Biomed Res Int. 2014;2014:236930.

Piowowar A. Advanced oxidation protein products. Part I. Mechanism the formationcharacteristics andproperty. Pol Merkur Lekarski. 2010;164(28):9-166.

Re R, Pellegrini N, Proteggente A, Pannala A, Yang M, RiceEvans C. Antioxidant activity applying an improved abts radical cation decolorization assay. Free Radic Biol Med. 1999;26(910):1231-1237.

Ribeiro EP, Seravalli EAG. Química de Alimentos. $2^{\mathrm{a}}$ ed. São Paulo: Edgard Blücher; 2007.

Ribeiro SO, Oliveira TT, Zatti RA, Silva SRS, Nagem TJ. Avaliação antioxidante de flavonóides de Citrussp. Anais Simpac Viços. 2010;2(1):47-52.
Ribeiro L de O, Mendes MF, Pereira C de S. Avaliação da composição centesimal, mineral e teor de antocianinas da polpa Juçai (Euterpe edulisMartius). Rev Eletrôn TECCEN. 2011;4(2):5-16.

Santos RO, Malvar B, Silva R, Ramlho V, Pessegueiro P, Amoedo M, et al. Contrast-inducednephropathy. Acta Med Port. 2011;24(5):809-820.

Scherer R, Godoy HT. Antioxidant activity index (AAI) by the 2, 2-diphenyl-1-picrylhydrazyl method. Food Chem. 2009; 1123:654-658.

Selistre LS, Souza VC, Dubourg L, Wagner MB, Filho JRH, Saitovitch D. Nefropatia induzida por contraste após tomografia computadorizada. J Bras Nefrol. 2015;37(1):27-31.

Silva GJF da, Constant PBL, Figueiredo RW de, Moura SM. Formulação e estabilidade de corantes de antocianinas extraídas das cascas de jabuticaba (myrciariassp.). Alim Nutr Araraquara. 2010;21(3):429-436.

Silva AC, Jorge N. Cogumelos: compostos bioativos e propriedades antioxidantes. J Health Sci. 2011;13(esp):375-384.

Silva PPM, Carmo LF, Silva GM, Silveira-Diniz MF, Casemiro RC, Spotp MHF. Composition of juçara pulp. Alimentos e Nutrição. Braz J Food Nutr Araraquara. 2013;24(1):7-13.

Souza CMM, Silva HR, Vieira-JR GM, Ayres MCC, Costa CLS, Araújo SD. Fenóis totais e atividade antioxidante de cinco plantas medicinais. Quím Nova. 2007;30(2):351-355.

Stajcic SM, Tepic AN, Djilas SM, Šumic ZM, ČanadanovicBrunet JM, Ćetkovic GS, et al. Chemical composition and antioxidant activity of berry fruits. APTEFF J. 2012;43:93-105.

Vedana MIS, Ziemer C, Miguel OG, Portella AC, Candido MB. Efeito do processamento na atividade antioxidante de uva. Alim Nutr Araraquara. 2008;19(2):159-165.

Wang J, Zhang Q, Zhang Z, Li Z. Antioxidant activity of sulfated polysaccharide fractions extracted from Laminaria japonica. Int J BiolMacromol. 2008;42(2):127-132.

Witko-Sarsat V, Friedlander M,Capeillère-Blandin C, NguyenKhoa T, Nguyen AT,Zingraff J, et al. Advanced oxidation protein products as a novel marker of oxidative stress in uremia. Kidney Int. 1996;49(5):1304-1313. 
Yokomaku Y, Sugimoto T, Kume S, Araki S, Isshiki K, ChinKanasaki M, et al. A Asialoerythropoietin prevents contrastinduced nephropathy. J Am Soc Nephrol. 2008;19(2):321-328.

Received for publication on $02^{\text {nd }}$ March 2018

Accepted for publication on $10^{\text {th }}$ October 2018 